\title{
Alterations in the laryngeal mucosa after exposure to asbestos
}

\author{
V KAMBIČ,' Z RADŠEL,' N GALE ${ }^{2}$ \\ From the Department of Otorhinolaryngology, ${ }^{1}$ and Institute of Pathology, ${ }^{2}$ University of Ljubljana, 61105 \\ Ljubljana, Yugoslavia
}

ABSTRACT The laryngeal mucosa of 195 workers in an asbestos cement factory (Salonit Anhovo, Yugoslavia) and in a control group was examined. The factory manufactures asbestos cement products containing about $13 \%$ of asbestos ( $8 \%$ amosite, $12 \%$ crocidolite, and $80 \%$ chrysotile) of different provenance. Alterations in the laryngeal mucosa were more frequent in the factory workers than in the control group. The changes, mostly consistent with chronic laryngitis, were closely related to the degree of workplace pollution and less so to the duration of employment. Ten workers exhibiting the most severe clinical changes underwent biopsy, the results of which showed histomorphological changes characteristic of hyperplastic chronic laryngitis. Four tissue specimens were examined also by scanning electron microscopy and in three of them asbestos fibres were found on the epithelial surface. No case of laryngeal carcinoma was identified. On the basis of our results it is thought that asbestos related changes of the larynx should receive more attention and that the use of the term "laryngeal asbestosis" is justified. The clinical picture is non-specific but in view of their frequency such changes should be considered a consequence of exposure to asbestos.

Exposure to asbestos is well known to cause bronchial carcinoma and mesothelioma and there are also reports of gastrointestinal tumours occurring in association with asbestos. ${ }^{1-6}$ By contrast, reports on a causal relation between asbestos and diseases of the upper airway, in particular changes in the laryngeal mucosa caused by exposure to asbestos, are comparatively scarce. We have found only a few reports of laryngeal carcinoma attributed to a high occupational exposure to asbestos. ${ }^{7-14}$ Diffuse inflammatory changes and localised alterations of the laryngeal mucosa (polyps and cysts) occurring as a result of asbestos activity have been described by Newhouse and coworkers." Apart from this paper, publications are largely limited to retrospective epidemiological and statistical studies or reports of individual cases of laryngeal carcinoma believed to have resulted from the patient's exposure to asbestos. These studies do not provide conclusive proof of a connection between laryngeal carcinoma and asbestos, hence the evidence regarding asbestos as a promoting factor for cancer of the larynx is considered as suggestive but as yet unproved. ${ }^{12}$

Over the past years, a pronounced increase in the number of patients with chronic changes in laryngeal mucosa has been observed in Slovenia, the northern-

Accepted 31 October 1988 most republic of Yugoslavia. Kambic and coworkers found pathological changes in the laryngeal mucosa in $78 \%$ of workers employed in severely polluted environments (glass works and metallurgical, chemical, leather, and textile industries).$^{15}$ The changes were mostly consistent with chronic hyperplasia, including precancerous lesions (hyperplasia atypica-risky epithelium) which are known from experience to be likely to turn malignant. ${ }^{16}$

Since a clustering of cases of chronic changes of the upper airway was observed in the area of an asbestos cement manufacturing plant, Salonit Anhovo, ${ }^{17}$ we decided to focus our attention on workers who are occupationally exposed to asbestos dust and performed ear, nose, and throat examinations in 195 workers of this factory.

\section{Subjects and methods}

Otorhinolaryngological examinations were carried out in 195 workers directly or indirectly exposed to asbestos dust in Salonit Anhovo, one of Yugoslavia's largest asbestos cement manufacturing plants, located on the Soca River close to the Yugoslav-Italian border. We also examined a control group of 50 subjects who were matched to the group of factory workers for age, sex, and personal habits. Our controls were inhabitants of a mountain settlement with 
Table 1 Distribution of subjects according to age and sex

\begin{tabular}{|c|c|c|c|c|c|c|}
\hline \multirow[b]{2}{*}{ Age } & \multicolumn{3}{|c|}{ Workers } & \multicolumn{3}{|c|}{ Control group } \\
\hline & Men & Women & Total & Men & Women & Total \\
\hline $\begin{array}{l}\leqslant 30 \\
31-40 \\
41-50 \\
51-60 \\
>60\end{array}$ & $\begin{array}{r}3 \\
40 \\
48 \\
30 \\
1\end{array}$ & $\begin{array}{r}2 \\
28 \\
36 \\
7 \\
0\end{array}$ & $\begin{array}{r}5 \\
68 \\
84 \\
37 \\
1\end{array}$ & $\begin{array}{r}3 \\
9 \\
11 \\
8 \\
0\end{array}$ & $\begin{array}{l}2 \\
7 \\
8 \\
2 \\
0\end{array}$ & $\begin{array}{r}5 \\
16 \\
19 \\
10 \\
0\end{array}$ \\
\hline Total & 122 & 73 & 195 & 31 & 19 & 50 \\
\hline
\end{tabular}

extremely favourable climatic conditions about $50 \mathrm{~km}$ from the factory who had never worked in the asbestos industry or some other polluted environment. We did not wish to use residents of Anhovo as controls because the entire town is more or less severely polluted with asbestos dust.

The final products of the factory (various types of asbestos cement boards, shingles, water and sewage piping) contain on average $13 \%$ of asbestos $(8 \%$ amosite, $12 \%$ crocidolite, and $80 \%$ chrysotile). Annually, 17000 tons of asbestos ore of different provenance (from Africa, USSR, or Canada) are processed in the factory. The plant has modern cleaning and ventilation facilities with built in filtering sacks made of "Gorotex."

The highest degree of pollution occurs in the units producing cement piping and boards. Measurements in June 1986 showed that asbestos concentrations exceeded $1.5 \mathrm{fibres} / \mathrm{ml}$ in seven of the 53 workplaces in the unit producing asbestos pipes and in five of the 33 workplaces producing asbestos boards. In the general area of the factory asbestos fibre concentrations ranging from 0.02 to $21.5 \mathrm{f} / \mathrm{ml}$ were measured at that time. In Yugoslavia appropriate standards are lacking. In the present study the concentration of airborne asbestos fibres in workplaces were determined by the membrane filter method (recommended technical method No 1, NIOSH, 1977).

Our group of 195 workers included 122 men and 73 women aged 23 to 64 (table 1). The duration of employment in the factory ranged from five to 31 years (table 2).

After blind clinical examinations, the workers were divided into three groups with respect to the degree of asbestos fibre pollution of the workplace, which was defined as follows:

Table 2 Duration of exposure to asbestos

\begin{tabular}{lc}
\hline Years of exposure & No of workers \\
\hline$\leqslant 10$ & 15 \\
$11-20$ & 78 \\
$21-30$ & 92 \\
$>30$ & 10 \\
Total & 195 \\
\hline
\end{tabular}

(1) mildly polluted working environment: $<0.5 \mathrm{f} / \mathrm{mP}$ (66 workers)

(2) moderately polluted working environment $0.51-1.5 \mathrm{f} / \mathrm{ml}$ ( 28 workers)

(3) severely polluted working environment: $>1.5 \mathrm{f}$ $\mathrm{ml}$ (101 workers).

The data on workplace pollution were obtained from the management of the plant.

A detailed history was obtained from each workerbefore clinical examination. The use of protective masks in areas with different levels of pollution is presented in table 3 . The group of workers include 5 101 non-smokers, 56 workers who had given ups smoking several years previously, and 38 curreng smokers. In the control group were 29 non-smokers $\frac{\mathbb{\Phi}}{\pi}$ 10 former smokers, and 11 current smokers. The ratio between smokers and non-smokers was similar in botho groups: 1:4.12 for the workers and 1:3.54 for fie control group. Regular use of alcohol was reported 23 workers and occasional use by 67; the rest were teetotal. A similar distribution was found in the control group (table 4).

Clinical examinations were performed by five oto 2 rhinolaryngologists from the department of otorhino $\overrightarrow{\vec{F}}$

Table 3 Use of protective mask in workplaces with various degrees of pollution

\begin{tabular}{llll}
\hline & \multicolumn{4}{c}{ Workplace pollution } \\
\cline { 2 - 4 } $\begin{array}{l}\text { Use of mask } \\
\text { by the worker }\end{array}$ & Mild & Moderate & Severe \\
& $<0 \cdot 5 \mathrm{f} / \mathrm{ml}$ & $0 \cdot 5-\mathrm{l} \cdot 5 \mathrm{f} / \mathrm{ml}$ & $>1 \cdot 5 \mathrm{f} / \mathrm{ml}$ \\
\hline Never & 66 & 18 & 36 \\
Occasionally & 0 & 7 & 49 \\
Always & 0 & 3 & 16 \\
Total & 66 & 28 & 101 \\
\hline
\end{tabular}

Table 4 Use of alcohol

\begin{tabular}{|c|c|c|}
\hline & Workers & Control group \\
\hline $\begin{array}{l}\text { None } \\
\text { Occasional } \\
\text { Habitual }\end{array}$ & $\begin{array}{r}105 \\
67 \\
23\end{array}$ & $\begin{array}{r}33 \\
13 \\
4\end{array}$ \\
\hline Total & 195 & 50 \\
\hline
\end{tabular}


laryngology and cervicofacial surgery in Ljubljana who used identical criteria. Results relating to the nose and pharynx will be presented in a separate report.

On the basis of the clinical picture, the laryngeal changes were grouped into the following categories: chronic laryngitis, acute laryngitis, posterior laryngitis, Reinke's oedema, vocal polyp, vocal node, and functional dysphonia. In all cases where the laryngological examination disclosed severe diffuse hyperplastic changes suspicious of malignant neoplasm, a laryngomicroscopy was carried out and a tissue sample was removed for histological study. In cases of Reinke's oedema and vocal polyps surgical removal for histological study also constituted a therapeutic procedure.

Ten biopsy specimens of chronic lesions of the laryngeal mucosa were examined by light microscopy. The tissue specimens were fixed in $10 \%$ neutral buffered formalin. The fixed specimens were routinely processed and embedded in semisynthetic paraffin wax. The tissue sections were stained with haematoxylin and eosin. The hyperplastic changes were evaluated using the Kambic-Gale classification..$^{1618}$

Small pieces of four biopsy specimens of laryngeal mucosa were examined by scanning electron microscopy (SEM). After fixation in 10\% neutral buffered formalin, the tissue samples were dehydrated in graded alcohols. The SEM specimens were dried by the critical point method with carbon dioxide. In a vacuum evaporator (JEOL ion sputter JFC 1100) the specimens were sputtered with gold and examined in a SEM JEOL 840 A.

\section{Results}

Table 5 presents the results of the clinical examination. Tables 6-9 show the distribution of cases of chronic laryngitis in the workers with respect to the degree of workplace pollution, duration of employment, smoking habits, and use of protective masks.

\section{LIGHT MICROSCOPY}

According to the Kambic-Gale classification the specimens were distributed into three groups ${ }^{16}$ : seven cases were of simple hyperplasia (fig 1), one of abnormal hyperplasia (fig 2), and two of atypical hyperplasia or risky epithelium (fig 3 ). No asbestos

Table 5 Diagnosis made by indirect laryngoscopy

\begin{tabular}{lll}
\hline Diagnosis & Workers & Control group \\
\hline Chronic laryngitis & 43 & 2 \\
Acute laryngitis & 9 & 1 \\
Posterior laryngitis & 3 & 0 \\
Reinke's oedema & 7 & 0 \\
Vocal polyp & 2 & 0 \\
Vocal node & 1 & 0 \\
Functional dysphonia & 8 & 0 \\
Total & 73 & 3 \\
\hline
\end{tabular}

Fig 1 Man aged 50. Simple hyperplasia. Epithelium is thicker, mainly because of cells in spinous layer; basal layer is unchanged. Keratinisation of epithelial surface is observed. (Haematoxylin eosin, orig magn $\times$ 105.) 
fibrils were detected in either the epithelium or the subepithelial stroma of any of the tissue specimens examined.

\section{SCANNING ELECTRON MICROSCOPY (SEM)}

In three of the four specimens asbestos fibres of variable lengths and diameters were observed on the surface of the squamous cell epithelium (figs 4 and 5). The observed rod like features of rigid fibres broke down into individual fibrils, which might explain why they could not be detected by light microscopy.

\section{Discussion}

It seems logical that in workers exposed to asbestos, changes in the upper airway, especially of the laryngeal mucosa, should be as frequent as diseases of the lungs.
If we paraphrase Barrett ${ }^{19}$ it would be hard to believe that asbestos fibres, as they travel through the nosez pharynx, and larynx to reach the lung parenchyma damage the lung but not the nose, pharynx, and

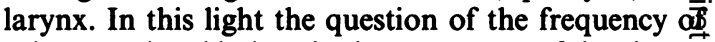
asbestos related lesions in the upper part of the airwaw is clearly rhetorical. This philosophy was the starting point of our investigation.

Alterations to the laryngeal mucosa are known to b. closely associated with alcohol consumption and smoking. Therefore the role of asbestos and other airborne mineral particles in the aetiology of laryngeaP carcinoma and other pathological changes of the laryngeal mucosa is difficult to appraise withoun taking into account these two factors.

The relative scarcity of reports on asbestos relate $\$$ changes in the laryngeal mucosa may be explained bid

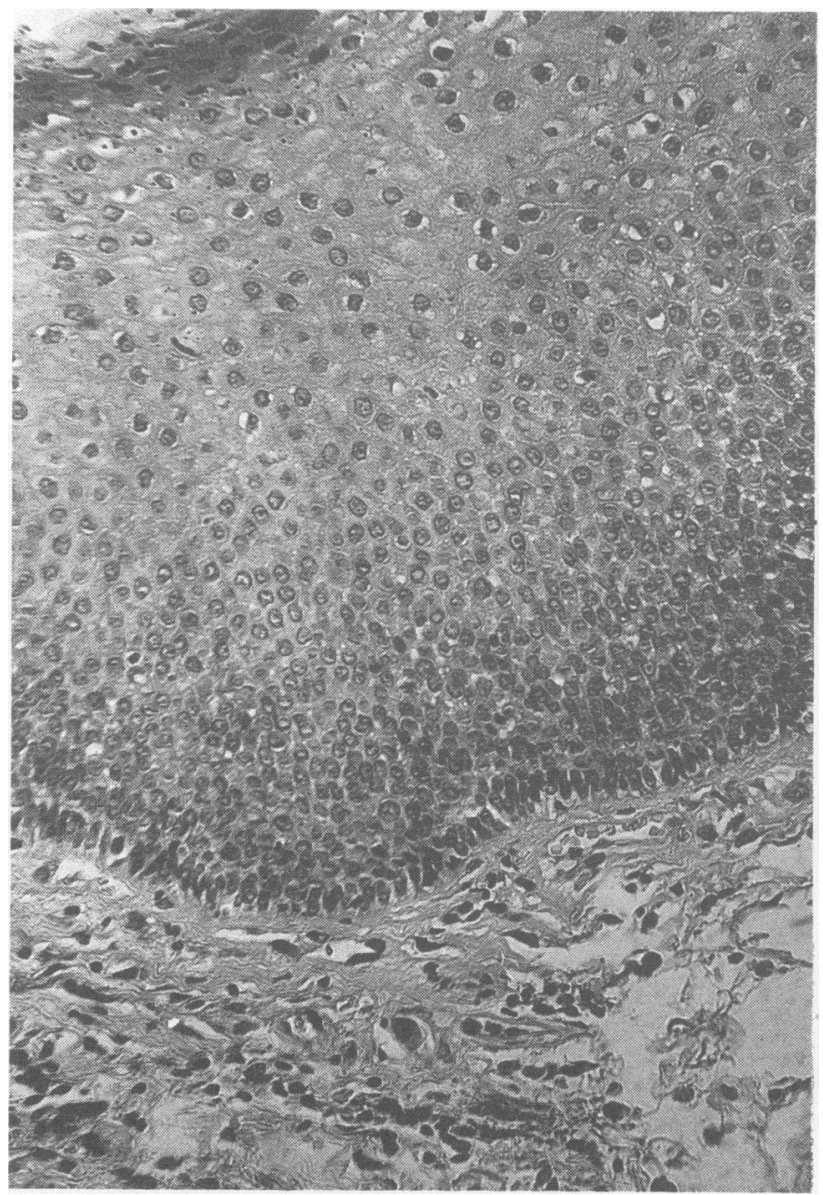

Fig 2 Man aged 48. Abnormal hyperplasia. Epithelium is thicker because of "basalification," cells of basal type extend up to middle of epithelium. (Haematoxylin eosin, orig magn $\times 64$.) 


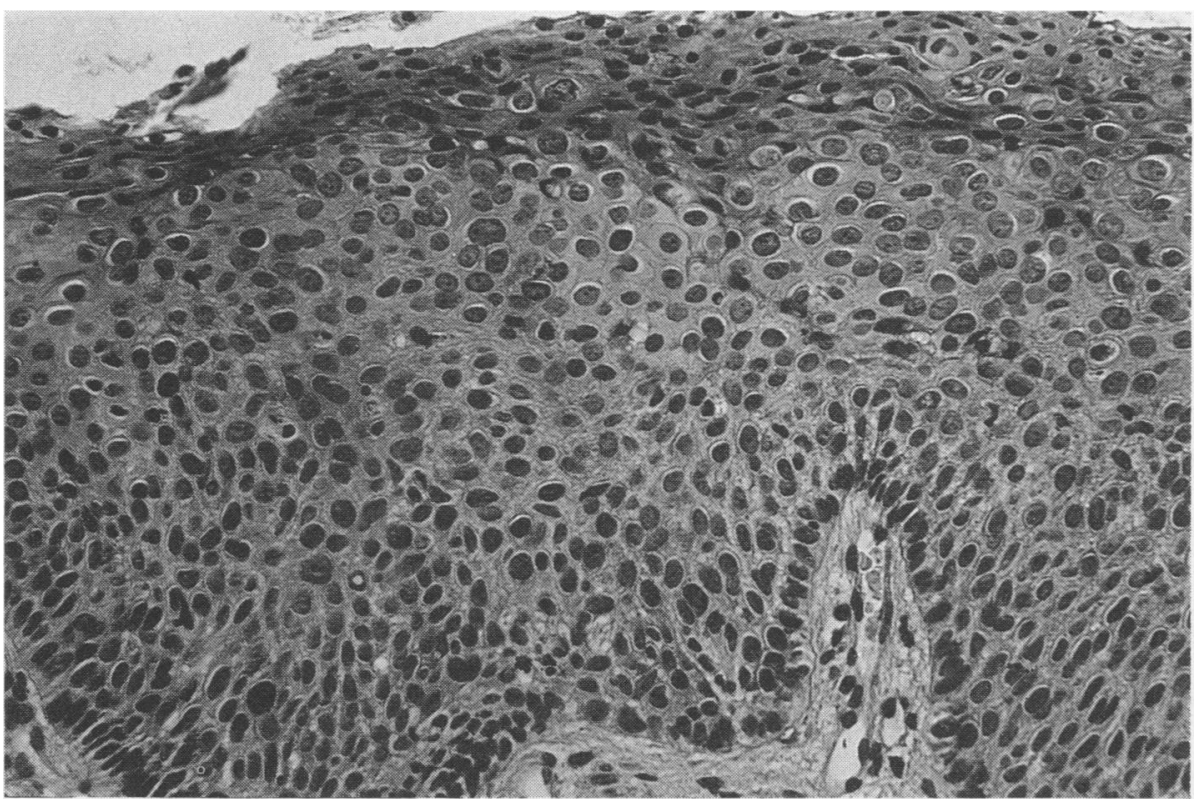

Fig 3 Man aged 56. Atypical hyperplasia-risky epithelium. Cells of entire hyperplastic epithelium have shape of basal cells. Nuclear cytoplasmatic ratio is increased, nuclei are slightly hyperchromatic.

(Haematoxylin eosin, orig magn $\times 105$.)

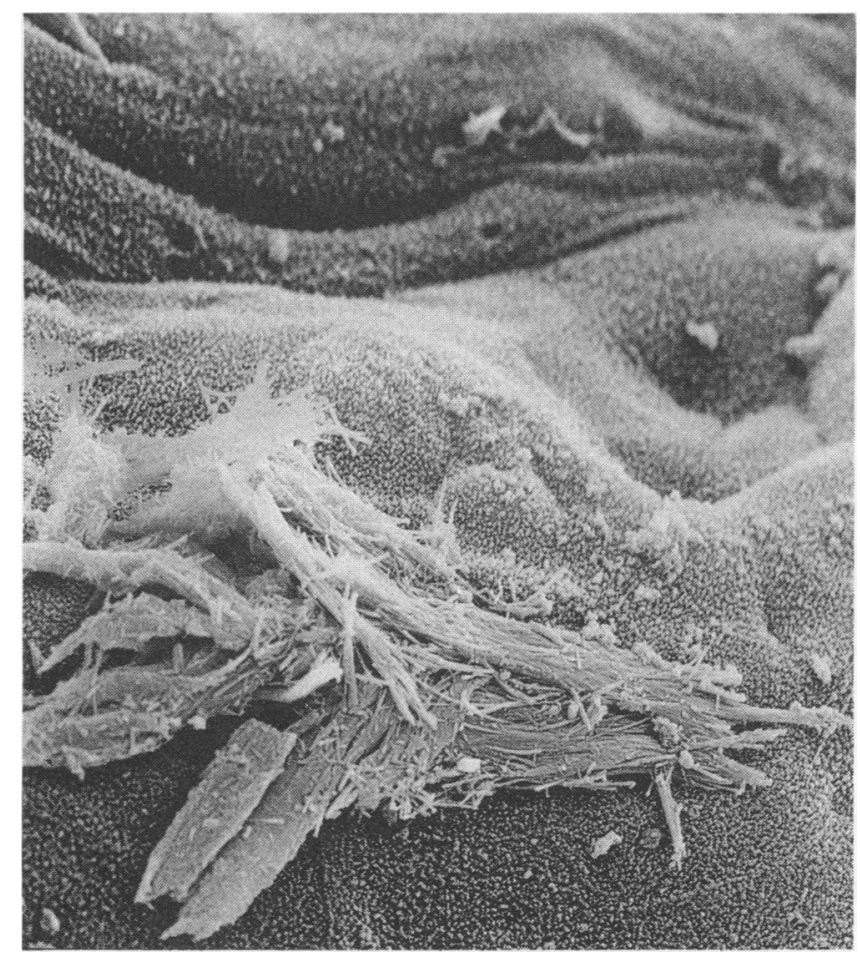

Fig 4 Man aged 53. Scanning photomicrograph. Surface of moderately bulging epithelium with rod like features of rigid fibres of variable lengths and diameters. 


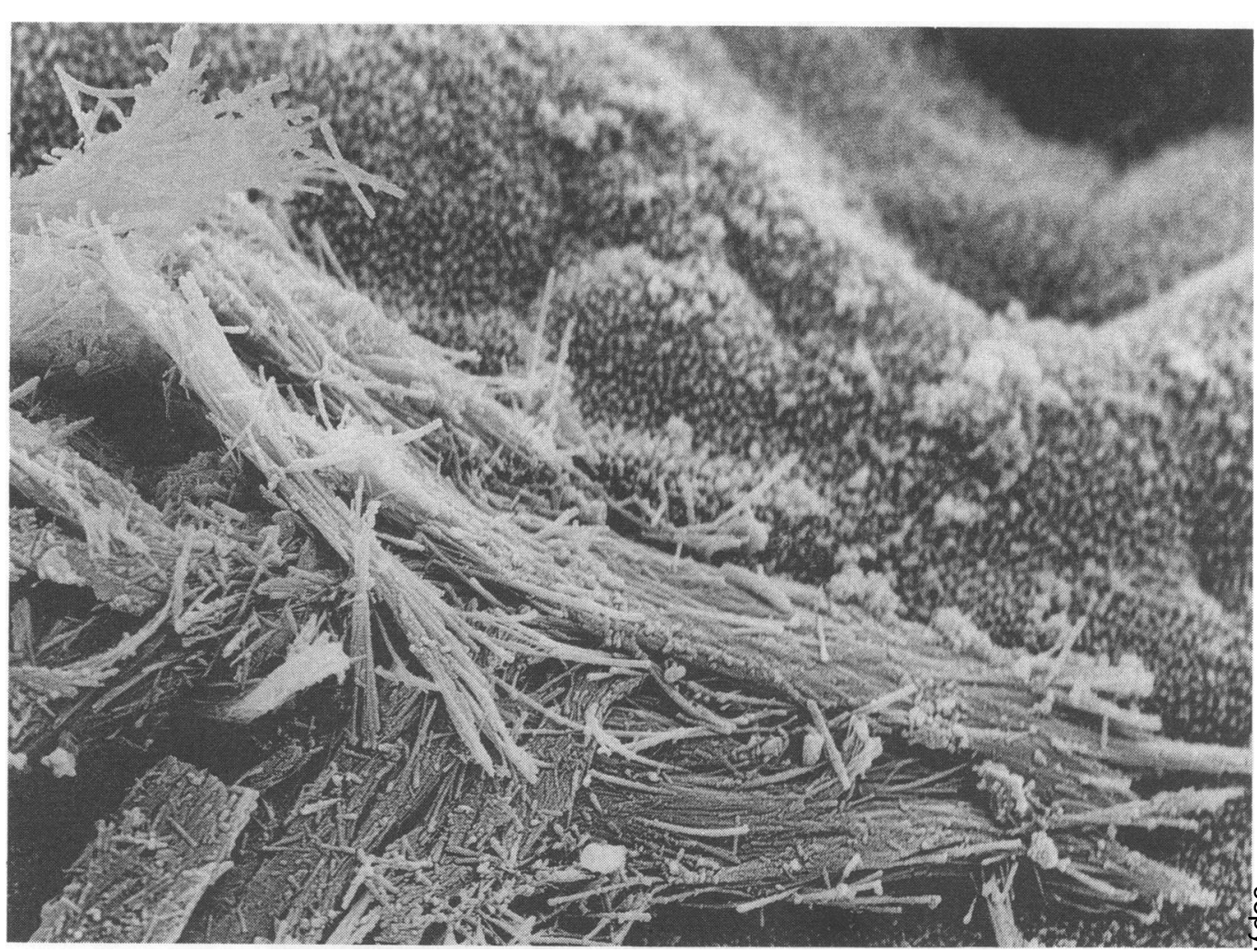

Fig 5 Same man as fig 4. Scanning photomicrograph. (Higher magnification.)

the fact that laryngologists take little interest in this problem, whereas other specialists who are commonly concerned with asbestosis and asbestos related diseases tend to underestimate laryngeal symptoms.

The results of our study show that the problem of asbestosis of the laryngeal mucosa is not unimportant. Among the 195 workers employed in an asbestos polluted environment, changes in the laryngeal mucosa were found in $73(37 \%)$; of these, 43 were consistent with chronic laryngitis and two were considered to be premalignant lesions on the basis of histological study. In three of the four tissue specimens studied by SEM asbestos fibres were found on the surface of the laryngeal epithelium. If these findings are compared with the results for the control group the harmful influence of asbestos on laryngeal mucosa is more than convincing.

In the group of workers examined the duration of exposure and the concentration of asbestos fibres in the workplace were important factors for the development of chronic laryngitis (tables 6 and 7).

No case of laryngeal carcinoma was found. Indeed, throughout the existence of the factory, the incidence of laryngeal carcinoma among the workers had noß exceeded that in the general population, which lend $\overrightarrow{5}$ support to Cowles's opinion that there is no conclusive evidence of a direct association between asbestos and

Table 6 Occurrence of chronic laryngitis among workers according to the degree of workplace pollution

\begin{tabular}{|c|c|c|}
\hline Workplace pollution & No of workers & Cases of laryngitis \\
\hline $\begin{array}{l}\text { Mild }<0.5 \mathrm{f} / \mathrm{ml} \\
\text { Moderate } 0.5-1.5 \mathrm{f} / \mathrm{ml} \\
\text { Severe }>1.5 \mathrm{f} / \mathrm{ml}\end{array}$ & $\begin{array}{r}66 \\
28 \\
101\end{array}$ & $\begin{array}{c}5(7 \cdot 5 \%) \\
4(14 \%) \\
34(33 \cdot 6 \%)\end{array}$ \\
\hline
\end{tabular}

Table 7 Occurrence of chronic laryngitis among workers according to duration of exposure to asbestos

\begin{tabular}{|c|c|c|c|}
\hline $\begin{array}{l}\text { Years of asbestos } \\
\text { exposure }\end{array}$ & No of workers & Cases of chronic laryngit & N \\
\hline $\begin{array}{l}\leqslant 10 \\
11-20 \\
21-30 \\
>30\end{array}$ & $\begin{array}{l}15 \\
78 \\
92 \\
10\end{array}$ & $\begin{array}{c}5(33 \cdot 3 \%) \\
19(24 \cdot 3 \%) \\
16(17 \cdot 4 \%) \\
3(30 \%)\end{array}$ & $\underset{\substack{\sigma \\
\frac{0}{D}}}{\stackrel{\sigma}{C}}$ \\
\hline Total & 195 & 43 & $\stackrel{9}{=}$ \\
\hline
\end{tabular}


Table 8 Smoking habits and chronic laryngitis among workers

Cases of chronic laryngitis

\begin{tabular}{ll}
\hline Non-smokers & 11 \\
Former cigarette smokers & 16 \\
Current cigarette smokers & 16 \\
Total & 43 \\
\hline
\end{tabular}

Table 9 Use of protective mask by workers with chronic laryngitis

\begin{tabular}{ll}
\hline Use of mask & No of workers \\
\hline Never & 21 \\
Occasionally & 20 \\
Always & 2 \\
Total & 43 \\
\hline
\end{tabular}

laryngeal cancer. ${ }^{12}$ Nevertheless, since we do not know the threshold for the development of malignancy or the latency period (which may be long), we cannot give a satisfactory answer to this question.

Since smoking is known to be a major cause of pathological changes in the laryngeal mucosa, it is surprising that in our group of workers laryngitis was not more common among smokers than among nonsmokers (table 8).

There was no difference in the occurrence of chronic laryngitis between workers who reportedly wore and those who did not wear protective masks. We doubt the validity of the information obtained from the patients, however. The use of the mask has been obligatory in the factory only since 1986 and it entitles the worker to additional pay. Despite this, masks are worn only exceptionally.

The results of our study support and justify the use of the term "laryngeal asbestosis." The clinical picture of the changes that might be considered under this diagnosis does not differ in any way from other forms of chronic hyperplastic disease. The vocal cords are swollen, red, or dull red in colour and show smaller or larger areas of keratosis but their movement is unimpaired.

The histomorphological picture of the changes caused by asbestos also does not differ from that found in chronic laryngitis, Reinke's oedema, or vocal polyp. Scanning electron microscopy is crucial for the diagnosis and in our study it showed asbestos fibres in three of the four specimens examined. Interestingly, all the fibres were located on the surface and none was beneath the epithelium.

Judging by the results of our study, all changes in the laryngeal mucosa in asbestos workers may be considered to result from exposure to asbestos, regardless of whether asbestos fibres are shown or not. Thus it seems appropriate to include diseases of the upper part of the airway, in particular of the larynx, in the range that can occur with exposure to asbestos.

In the present survey the status of the lungs was not taken into account, although we think that a comparison between the occurrence of asbestosis in the lower and upper parts of the airway would be of great interest; this will be the subject of further study.

Requests for reprints to: Professor Dr Vinko Kambic, Department of Otorhinolaryngology, University of Ljubljana, 61105 Ljubljana, Zaloska 2, Yugoslavia.

\section{References}

1 Chiappino G. Quali effeti nell'uomo da basse espositioni agli asbesti. Med Lav 1985;76:179-91.

2 Mossman BT, Cameron GS, Yotti LP. Cocarcinogenic and tumor promoting properties of asbestos and other minerals in tracheobronchial epithelium. Carcinog Compr Surv 1985;8:217-38.

3 Roggli VL, Pratt PC, Brody AR. Asbestos content of lung tissue in asbestos associated diseases: a study of 110 cases. $\mathrm{Br} \mathrm{J}$ Ind Med 1986;43:18-28.

4 Rubino GF, Piolato G, Newhouse ML, Scansetti G, Aresini GA, Murray R. Mortality of crysotile asbestos workers at the Balangero mine, Northern Italy. Br J Ind Med 1979;36:187-94.

5 Ehrlich A, Rohl AN, Holstein EC. Asbestos bodies in carcinoma of the colon in an insulation worker with asbestosis. JAMA 1985;20:2932-3.

6 Berry G, Newhouse ML. Mortality of workers manufacturing friction materials using asbestos. Br J Ind Med 1983;40:1-7.

7 Newhouse ML, Berry G. Asbestos and laryngeal carcinoma. Lancet 1973;ii:615.

8 Shettigara PT, Morgan RW. Asbestos, smoking and laryngeal carcinoma. Arch Environ Health 1957;30:517-9.

9 Burch JD, Howe GR, Miller AB, Semenciw R. Tobacco, alcohol, asbestos and nickel in the etiology of cancer of the larynx: a case control study. JNCI 1981;67:1219-24.

10 Stell PM, McGill T. Asbestos and laryngeal carcinoma. Lancet 1973;ii:416-7.

11 Newhouse ML, Gregory MM, Shannon H. Etiology of carcinoma of the larynx. IARC Sci Publ 1980;30:687-95.

12 Cowles SR. Cancer of the larynx: occupational and environmental associations. South Med J 1983;76:894-8.

13 Blot WJ, Morris LE, Stroube R, Tagnon I, Fraumeni JF. Lung and laryngeal cancers in relation to shipyard employment in coastal Virginia. JNCI 1980;65:571-5.

14 Selikoff J, Seidman H, Hammond EC. Mortality effects of cigarette smoking among amosite asbestos factory workers. JNCI 1980;65:507-13.

15 Kambič V, Radšel Z. Poskus razčlenitve zunanjih dejavnikov, ki vplivajo na patološke spremembe v grlu. Zdravstveni Vestnik 1979;48:149-51.

16 Kambič V, Gale N. Significance of keratosis and dyskeratosis for classifying hyperplastic aberrations of laryngeal mucosa. Am J Otolaryngol 1986;7:323-33.

17 Fischinger J. Epidemiologija bolezni grla v SR Sloveniji. Zdravstveni Vestnik 1981;50:627-31.

18 Meyer-Breiting E, Burkhardt A. Tumors of the larynx. Berlin: Springer Verlag, 1988:66.

19 Barett NR. The pleura with special reference to fibrothorax. Thorax 1970;25:515-24. 